\title{
TENSE AND MODALITY IN THE NOMINAL DOMAIN**
}

\section{INTRODUCTION}

Tense and modality have been topics of high interest to linguists. The semantic and syntactic properties of these elements and their interaction at the sentential level have been widely investigated (on tense, see, among many others, Stowell 1982, 1992, 1995, 2000, 2007; Comrie 1985; Abusch 1988, 1997; Ogihara 1995; Steedman 1997; and on modality, see Kratzer 1977, 1981, 1991, 2012, 2013; Palmer 1990, 2001; Nuyts 1993, 2001, 2006; Narrog 2005; von Fintel 2006; Hacquard 2006, 2010, 2011; Portner 2009; among others). Crucially, it has been convincingly argued that in the cartography of syntactic structure, epistemic modals are base-generated and interpreted higher than Tense $(\mathrm{T})$, whereas root (non-epistemic) modals are base-generated and interpreted lower than T (e.g., Cinque 1999, 2004, 2013; Butler 2003; Hacquard 2010).

At the subsentential level, however, the literature is limited to the study of temporality and mood in the nominal domain and their syntactic representations as nominal tense and nominal mood, leaving much space for research and discoveries. Musan $(1995,1997,1999)$ observes that noun phrases can be modified by various kinds of temporal expressions and that these temporal modifiers can modify nouns denoting life-time or temporary properties. Lecarme (1996, 2004, 2008), Sadler and Nordlinger (2001) and Nordlinger and Sadler $(2003,2004 a, 2004 b)$ point out that nominals are inflected for tense, aspect and mood in a number of languages (e.g., Halkomelem and Guaraní). Contra this, Alexiadou $(2001,2005)$, based on the absence of phenomena related to T (namely, Extended Projection Principle (EPP), Exceptional Case Marking (ECM) and raising) in nominals, argues that these constructions lack a tense projection.

The main objective of this article is to show that, similar to the structure of Complementizer Phrases (CPs), epistemic and root modal elements have different positions in Determiner Phrases (DPs); epistemic adjectives appear in the specifier of $\operatorname{Mod}_{\text {epis. } \mathrm{N}} \mathrm{P}$ above nominal tense $\left(\mathrm{T}_{\mathrm{N}} \mathrm{P}\right)$, while root adjectives appear in the specifier of $\operatorname{Mod}_{\text {root. } \mathrm{N}} \mathrm{P}$ below $\mathrm{T}_{N} \mathrm{P}$. With this aim in view, the structure of the article is as follows. In section 2 , we will have a brief look at tense and modality in the verbal domain to which I seek some parallelism in the nominal domain. In section 3, I elaborate on the concept of

\footnotetext{
* n.ilkhanipour@ut.ac.ir

** A previous version of this article was presented at SinFonIJA 8 in Ljubljana, 24-26 September 2015. I would like to thank the organizers and the audience of that conference for their feedback. Also, I am grateful to two anonymous reviewers of Linguistica for their insightful comments.
} 
temporality in nominals. I importantly discuss that we need some extending-into-time perspective in noun phrases and that this extending-into-time perspective is syntactically represented as nominal tense. In section 4, I move on to some data from Persian and show that the temporal adjective qæbli 'previous' is, in effect, ambiguous. In section 5, based on the ambiguity of the temporal adjective qæabli 'previous', I argue that epistemic and root adjectives (e.g., Pehtemali 'probable' and qabel-e-PePtemad 'reliable', respectively) occupy different positions with regard to the nominal tense. Finally, in section 6 , I wrap up the article with some concluding remarks.

\section{THEORETICAL PRELUDE}

The literature on tense and modality in the verbal domain is vast and burgeoning. In this section, I hardly attempt to summarize the diverse and insightful findings of previous studies. Rather, I wish to pursue the idea that epistemic modals $\left(\operatorname{Mod}_{\text {epis }}\right)$ are basegenerated higher than root modals $\left(\mathrm{Mod}_{\mathrm{root}}\right)$ in the clausal structure. To put it precisely, as illustrated in (1), epistemic modals are higher than $\mathrm{T}$, while root modals are lower than T (e.g., Cinque 1999, 2004, 2013; Butler 2003; Portner 2009). ${ }^{1}$

(1) $\operatorname{Mod}_{\text {epis }}<\mathrm{T}<\operatorname{Mod}_{\text {root }}$

Maintaining Kratzer's $(1981,1991)$ original account that each modal has a single lexical entry which is not specified for a particular flavor (epistemic or root), Hacquard (2010) shows that modal auxiliaries, such as must and can, may freely appear above or below $\mathrm{T}$ and that the individual relativity and the time relativity of modals go hand in hand, yielding the event relativity of modal elements: epistemic modals, base-generated in the high position above TP, are evaluated in the context of the speech event, that is, with regard to the speaker at the speech time, while root modals, base-generated in the low position above VP, are evaluated in the context of the VP event, with regard to one of the participants of the event, represented as an argument, at the event time. This is illustrated in (2).

(2)

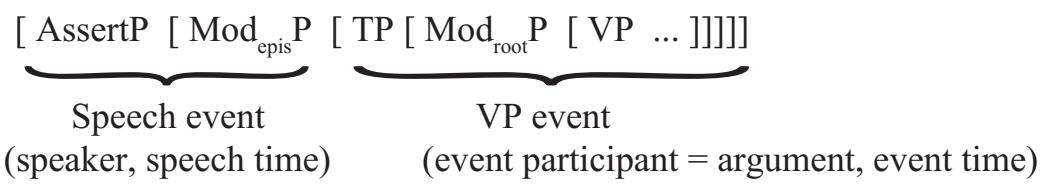

According to Hacquard's (2010) analysis, the ambiguity of (3) for the modal readings (epistemic and root) is due to the two different structural positions that must may occupy in the derivation: when merged above $\mathrm{T}$, it is evaluated in the context of the speech event, as in (3a), and when merged lower than $T$, it is evaluated with regard to the VP event, as in (3b).

1 I remain agnostic to the finer distinctions of epistemic and root modals (see Cinque 1999, 2004, 2013). 
(3) The winners must have been in the court at noon.

a. $\operatorname{Mod}_{\text {epis }}<\mathrm{T}$ : epistemic reading: it is necessary, given what is known now by the speaker, that the winners were in the court at noon.

b. $T<\operatorname{Mod}_{\text {root }}$ : root reading: it was necessary, given the rules of the event then, that the winners were in the court at noon.

In the rest of this article, I argue that parallel to the structure of the verbal domain in (2), epistemic and root modal elements occupy different positions in DPs; epistemic adjectives appear above nominal tense and are interpreted in the context of the speech event, while root adjectives appear in a lower position, interpreted in the context of the NP event. This is illustrated in (4) where the subscript N indicates the nominal stance of the projection.

(4) $[\underbrace{\operatorname{Assert}_{N} \mathrm{P}\left[\operatorname{Mod}_{\text {epis. }} \mathrm{P}\right.}_{\text {Speech event }}[\underbrace{\left.\left.\mathrm{T}_{\mathrm{N}} \mathrm{P}\left[\operatorname{Mod}_{\text {root.N }} \mathrm{P}[\mathrm{NP} \ldots]\right]\right]\right]}_{\mathrm{NP} \text { event }}]$

To reach (4), first we should ascertain that temporality is an indispensable concept in noun phrases and that the temporal dimension of nominals is syntactically represented via Nominal Tense $\left(\mathrm{T}_{\mathrm{N}}\right)$.

\section{TEMPORALITY AND TENSE IN NOMINALS}

The modification of noun phrases with temporal expressions and the temporal relation between predicates and their arguments are two pieces of evidence for considering an extending-into-time perspective for nominals.

First, as observed by Musan (1995), noun phrases can be modified by various kinds of temporal expressions, as shown in (5). These temporal modifiers can modify nouns denoting life-time or temporary properties, as in (5a) and (5b), respectively.

(5) a) clausal modifiers: [The war when my grandfather was young] lasted four years.

b) genitive modifiers: [The sixties' rebels] are quite established today.

c) adverbial modifiers: [The quarrel yesterday] was totally superfluous.

d) adjectival modifiers: [The present wife of Klaus] is [a former student of his].

e) prepositional modifiers: [The chancellor in 1989] made some serious mistakes.

(Musan 1995:160, (1a-e))

The temporal modification of noun phrases leaves space for the hypothesis that nominals, similar to verbals, refer to situations that hold at certain times (see also Musan 1999).

Second, the unacceptability of the sentences in (6) can be justified if we credit the arguments my future job and the present president with some temporal dimension modified by the temporal adjectives future and present (see also Enç 1987). 
(6) a) \#Last week I was dismissed from my future job.

b) \#The present president will be elected (president) shortly. (where every person can be president only once)

A relevant discussion of the temporal relation between predicates and their arguments can be found in Musan $(1995,1997,1999)$ where EXISTENCE-IMPLYING predicates, including individual-level predicates (e.g., to be from America) and stage-level predicates (e.g., to be happy), are assumed to impose a presuppositional condition on their arguments' being in existence or alive. Musan also points out that noun phrases can receive temporally dependent or independent readings:

A noun phrase occurrence is temporally dependent if and only if its situation time has to intersect with the situation time of the main predicate of its clause.

A noun phrase occurrence is temporally independent if and only if its situation time does not have to intersect with the situation time of the main predicate of its clause. (Musan 1999:622)

Now the question is whether there exists a tense projection in the nominal spine. Alexiadou $(2001,2005)$ points out that there are two features associated with T: the EPP feature and the [assign nominative] feature. She further discusses that the phenomena related to T, namely EPP, ECM and raising, are absent in nominals and thus noun phrases lack a tense projection (Alexiadou 2001:59-66).

(7) EPP in CP and DP

a) There arrived a man.

b) *there's arrival

(Alexiadou 2001: 60, (83a-b))

(8) ECM in CP and DP

a) I believe Mickey to be a genius.

b) *my belief of Mickey to be genius

(Alexiadou 2001: 60, (88) and (89))

(9) Raising in CP and DP

a) Mary appears to have left.

b) *Mary's appearance to have left

(Alexiadou 2001: 60, (84) and (85))

While Alexiadou (2001) takes these as pieces of evidence for the absence of tense in noun phrases, I take them as evidence for some featural difference between clausal and nominal tense. Recall that $\mathrm{D}$ is the nominal counterpart of $\mathrm{C}$ and that $\mathrm{D}$ and $\mathrm{C}$ do not share the same features or interpretations. So, I submit that it is possible that $T_{N}$ and $\mathrm{T}$ do not share the same features or interpretations and consequently, that $\mathrm{T}_{\mathrm{N}}$ is the nominal counterpart of $\mathrm{T}$. 
On the other hand, the presence of tense in the extended projection of noun phrases is fruitful. Looking with favour upon Cinque's $(1994,2010)$ and Scott's (2002) proposal that adjectives are base-generated in the specifiers of distinct functional projections to which they are associated, I consider that the location of temporal adjectives (e.g., present and former in (5d)) is Spec, $\mathrm{T}_{\mathrm{N}} \mathrm{P}$. Nominal Tense is then a functional projection that not only provides the necessary space for temporal adjectives but also contributes to the temporal interpretation of nouns.

Moreover, according to Lecarme (1996, 2004, 2008), Sadler and Nordlinger (2001) and Nordlinger and Sadler (2003, 2004a, 2004b), among others, nominals are inflected for tense, aspect and mood in a number of languages. In Halkomelem and Guaraní, as shown in (10) and (11), the same set of affixes mark tense on nominals and verbal predicates. Nominal past tense encoding meanings such as 'former, -ex, late (dead)' temporally locates the nominal. When used with a possessed inanimate noun, the temporal marker indicates that the possession relation was in the past, or that the possessed item has been destroyed (Burton 1997:67-68). ${ }^{2}$

te sqwemá:y-elh (Halkomelem)
the dog-pst
'the dead dog'
(Sadler and Nordlinger 2001)

(11)
che-róga-kue
(Guaraní)
1sg-house-pst
'my former house'
(from Nordlinger and Sadler 2004a)

The morphological expression of time within the nominal domain provides evidence for the idea that $\mathrm{T}$ does not exclusively combine with verbs (cf. Panagiotidis 2011, 2015).

And last but not least, the study of temporality in the nominal domain and assuming that $\mathrm{T}_{\mathrm{N}}$ is a functional projection in the nominal spine provide an exciting opportunity to advance our knowledge of the possible orders of adjectives. In particular, we find the way to realize that epistemic adjectives are higher than $T_{N}$, whereas root adjectives are lower than $\mathrm{T}_{\mathrm{N}}$. To achieve this order, I start the argument with discussing the ambiguity of the Persian adjective qæabli 'previous' in the next section.

\section{PERSIAN 'PREVIOUS': ORDINAL/TEMPORAL ADJECTIVE}

The Persian adjective qæebli 'previous' in (12) is ambiguous; it may have a temporal reading, as in context $\mathrm{A}$, or an ordinal reading, as in context $\mathrm{B}$.

2 Tonhauser $(2006,2007)$ argues that nominal temporal markers in Paraguayan Guaraní are aspect (and not tense) markers. It is beyond the scope of this study to decide on aspect/tense analysis of nominal temporal markers in this language. 
bærænde-ye qæbli

winner-Ez previous

'the previous winner'

Context A: The Temporal Reading

The host of a quiz show talks about the winner of the previous round.

In this context, the host says the sentence in (13).
(13) bærænde-ye qæbli tehrani bud
winner-EZ previous Tehrani be.PST.3SG
'The previous winner was from Tehran.'

In context A, being the winner is referred to a property in the past. The previous winner does not hold the title any more in the speech time of (13).

Context B: The Ordinal Reading

In a quiz show with two winners, the host introduces first winner 1 and then winner 2 .

While introducing winner 2 in context B, the host says the sentence in (14).

(14) Pin bærænde mesl-e bærænde-ye qæbli tehrani-e this winner like-Ez winner-Ez previous Tehrani-be.3sG 'This winner, like the previous winner, is from Tehran.'

Here, the property of being the winner in the DP bærænde-ye qæbli 'the previous winner' is held at the speech time. The adjective qæbli 'previous' does not make being the winner a property in the past. Instead, it puts an order on the two winners and thus, plays the role of an ordinal number. The sentence in (14) as put in context B can be paraphrased as in (15).

\section{(15) Pin bærænde mesl-e bærænde-ye Pævvæl tehrani-e This winner like-Ez winner-Ez first Tehrani-be.3sG 'This winner, like the first winner, is from Tehran.'}

The ambiguity of (12) does not come from two distinct lexical entries for the adjective qæbli 'previous'. It is indeed due to the two different positions that this adjective may occupy in the course of the syntactic derivation of the DP: the specifier of $\mathrm{T}_{\mathrm{N}} \mathrm{P}$ in context $\mathrm{A}$, as in (16a), that gives rise to the temporal reading, and the specifier of ordinalP in context $\mathrm{B}$, as in (16b), that brings about the ordinal reading. ${ }^{3}$

3 In this article, I disregard the syntactic nature of Ezafe. For discussions on this element in Persian, see Samiian 1994, Ghomeshi 1997, Abolghasemi 2002, Larson and Yamakido 2005, DeLazero and Geraee 2014, and references therein. However, it is worth mentioning that the occurrence of Ezafe independent of the syntactic and semantic nature of the elements in the nominal domain (consider the fact that Ezafe appears on nouns and also on adjectives, and that it appears on both root and epistemic modal adjectives, as well as temporal adjectives) assures that this element does not play any role in the discussion of this research. 
(16) a)

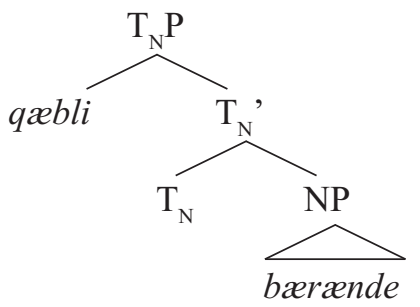

b)

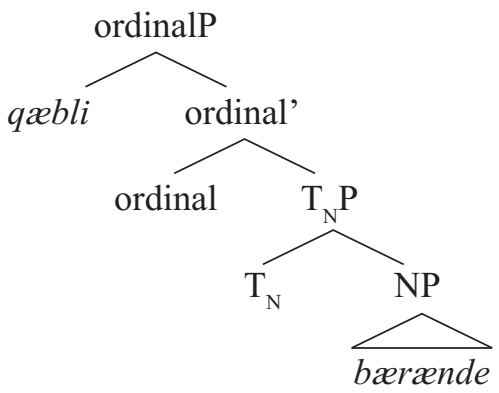

The proposal that the adjective qæabli 'previous' can be base-generated in two structural positions is supported by the co-occurrence of the two readings. ${ }^{4}$ Consider context C.

Context C: Co-Occurrence of the Temporal and Ordinal Readings

In a quiz show, the host introduces the two winners of the previous round, first winner 1 of the previous round and then winner 2 of the previous round.

In this context, the host refers to winner 2 of the previous round as in (17).
bærænde-ye qæbli-ye qæbli winner-EZ previous-EZ previous 'the previous previous winner'

Here, the first qæebli 'previous' (the one closer to the modified noun) indicates that the property of being the winner was held in the past (and not at the speech time) and the second qæebli 'previous' puts an order on the two winners of the previous round. The syntactic positions of the two adjectives are illustrated in (18). ${ }^{5}$

4 I am thankful to Marcel den Dikken for bringing this point to my attention, and to Guglielmo Cinque for a short but thoughtful discussion on this.

5 A reviewer pointed out that the ordinal previous and the temporal previous can be separated by a numeral in English: the previous two previous winners (see also Cinque 2015:24, fn. 4). This cannot be observed in Persian because numerals precede nouns, while temporal and ordinal adjectives follow them. The order in Persian is as illustrated in (i) and exemplified in (ii) below. The example in (ii) is ambiguous: it can be read as in (ii.a), or as in (ii.b).

(i) Number Noun-EZ Adjective-EZ Adjective 
(18)

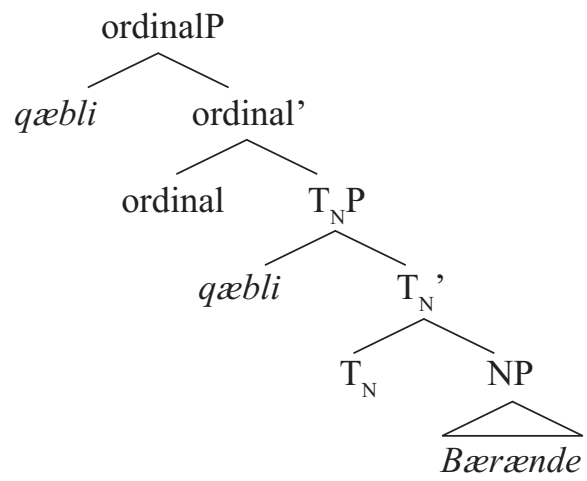

In the next section, I will employ the structural ambiguity of qæebli 'previous' to show that epistemic adjectives are base-generated higher than $\mathrm{T}_{\mathrm{N}}$ while root adjectives occupy a lower position. ${ }^{6}$

\section{MODAL ADJECTIVES IN ORDER}

In Persian, the notion of modality can be expressed via modal adjectives in the nominal domain. Examples $(19 \mathrm{a}-\mathrm{b})$ are instances of epistemic and root modal adjectives in Persian (Ilkhanipour and DeLazero 2013; Ilkhanipour 2015).
a) bærænde-ye Pehtemali winner-EZ probable 'the probable winner'
b) bærænde-ye qabel-e-PePtemad-e winner-EZ reliable 'the reliable winner'

In the following lines of this section I argue for the fixed order of adjectives in (20), and since I regard adjectives as merged in the specifiers of functional projections, for the hierarchy of functional projections in the nominal spine in (21).

$\begin{array}{llll}\text { (ii) do bærænde-ye } & \text { qæbli-ye } & \text { qæbli } \\ \text { two winner-Ez } & \text { previous-Ez } & \text { previous }\end{array}$

a. do [bærænde-ye qæbli-ye qæbli]

'the two previous previous winner'

b. [do bærænde-ye qæbli]-ye qæbli 'the previous two previous winner'

6 It should be noted that the word order in Persian noun phrases (e.g., Noun-EZ Adjective-EZ Adjective in (17)) does not conflict with the "structural" hierarchy of the syntactic elements (e.g., as illustrated in (18)). My assumption here is "[...] that what reaches the mind lacks order, while what reaches the ear is ordered. Linear order, then, should not enter into the syntactic-semantic computation. Rather, it is imposed by externalization, presumably as a reflex of properties of the SM system, which requires linearization [...]" (Chomsky 2015:19). 
(20) ordinal adjective $<$ epistemic adjective $<$ temporal adjective $<$ root adjective

(21) $\quad$ ordinalP $<\operatorname{Mod}_{\text {epis.N }} \mathrm{P}<\mathrm{T}_{\mathrm{N}} \mathrm{P}<\operatorname{Mod}_{\text {root. } \mathrm{N}} \mathrm{P}$

\subsection{Root Adjectives: Below $\mathbf{T}_{\mathbf{N}}$}

The structural ambiguity of qæbli 'previous' is observed when it co-occurs with root adjectives, such as qabel-e-PePtemad 'reliable', as in (22).

(22) bærænde-ye qabel-e-PePtemad-e qæbli winner-EZ reliable-EZ previous 'the previous reliable winner'

The DP in (22) can be uttered in both contexts A and B, as defined above. Importantly, it is acceptable in context A with the temporal reading of $q æ b l i$ 'previous'.

Moreover, the root adjective qabel-e-PePtemad 'reliable' can modify the noun in context $\mathrm{C}$ where the two readings of qæabli 'previous' co-occur. This can be seen in (23).

(23) bærænde-ye winner-EZ 'the previous previous reliable winner'

$$
\text { qabel-e-PePtemad-e }
$$$$
\text { reliable-EZ }
$$

\section{qæbli-ye}

previous-EZ $q æ b l i$

previous

These pieces of evidence suggest that the position of the root adjective is lower than $\mathrm{T}_{\mathrm{N}}$, as shown in (24).

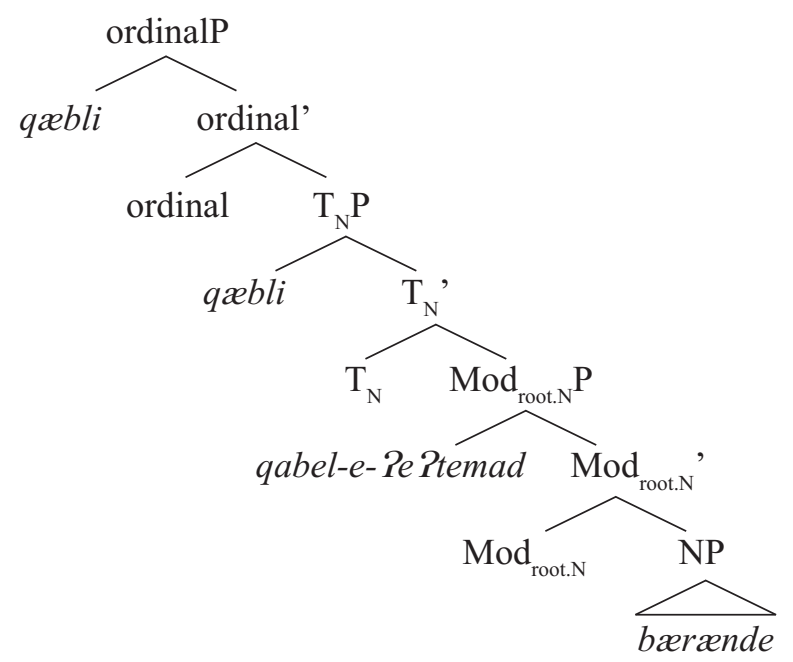

The root adjective qabel-e-PePtemad 'reliable' is then interpreted with respect to the modified noun bærænde 'winner' at the time of the quiz show. The quiz show is, in effect, the NP event against which the root adjective is evaluated. The individual 
involved in this event is the role noun bærænde 'winner' and the time of the event is syntactically represented as $T_{N}$, the time of being the winner or winning here.

Reordering the temporal and the root adjectives, as in (25), we still find both readings of qæabli 'previous' available. The phrase in (25) is marked, though, with heavy stress on the root adjective qabel-e-Pe?temad 'reliable'.

$\begin{array}{ccl}\text { (25) ?bærænde-ye } & \text { qæbli-ye } & \text { qabel-e-PePtemad } \\ \text { winner-EZ } & \text { previous-EZ } & \text { reliable } \\ \text { '?the reliable previous winner' } & \end{array}$

The order of adjectives in (25) can be accounted for if we consider a focus phrase in the nominal domain and move the root adjective from its original position to the specifier of the focus phrase, as illustrated in (26) (on focus in nominals, see Aboh 2004; Giusti 2005; Angitso 2015; among others). ${ }^{7}$

7 As correctly pointed out by a reviewer, what remains to be determined is whether this focus position is available as a means to subvert the order of direct modification adjectives. To check that, one should select two exclusively non-predicative adjectives, otherwise it could simply be that the apparent order subversion is a function of using one as a direct modification and one as an indirect (reduced relative clause) modification (cf. Cinque 2010:32). In Persian temporal and ordinal adjectives are the only instances of exclusively non-predicative adjectives. As can be seen in (i) and (ii), qæbli 'previous' and bæ Pdi 'next' with both their temporal and ordinal readings cannot occur in the predicate position.
(i) a) modir-e qæbli
manager-EZ previous
'the previous manager'
b) *modir qæbli Pæst
manager previous be.3sg
'*The manager is previous.'
(ii) a) modir-e $\quad$ bre $\mathrm{Pdi}$
manager-Ez next
'the next manager'
b) *modir bæe Pdi Pæst
manager next be.3sg
'*The manager is next.'

Now consider employing qæbli 'previous' with its temporal reading and bæ Pdi 'next' with its ordinal reading co-modifying the noun modir 'manager' in a context where there exists two previous managers and the speaker introducing the second previous manager utters the DP in (iii).
(iii) modir-e qæabli-e bæ?di
manager-EZ previous-EZ next
'the next previous manager'

The temporal adjective qæbli 'previous' in (iii) can be focalized; it moves from Spec, $\mathrm{T}_{\mathrm{N}} \mathrm{P}$ to the Spec,FocusP and is pronounced with heavy stress, as illustrated in (iv).
(iv) ?modir-e bæ Pdi-e qabli
manager-EZ next-EZ previous

So, as can be seen, FocusP can be used as a means to subvert the order of direct modification adjectives in Persian. 


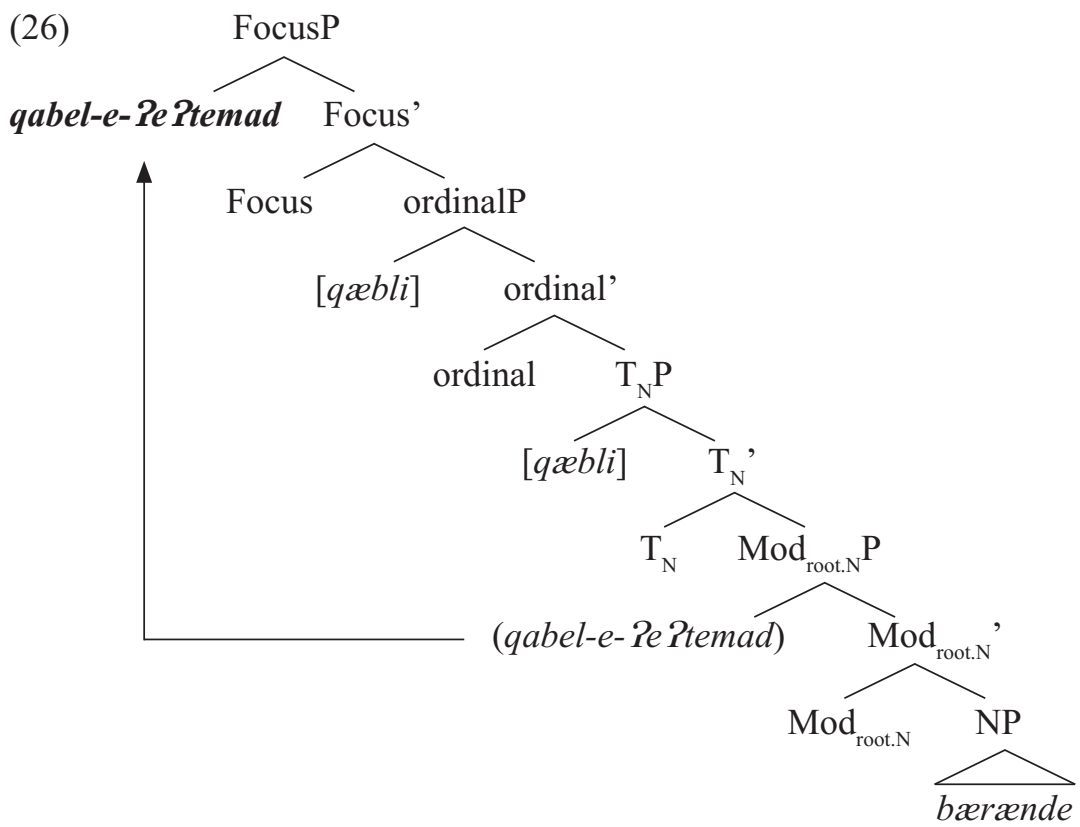

\subsection{Epistemic Adjectives: Above $T_{\mathrm{N}}$}

With epistemic adjectives, such as Pehtemali 'probable', as in (27), the adjective qrbli 'previous' is not ambiguous; it can be interpreted only as in context $\mathrm{B}$, that is, as an ordinal modifier.

\section{(27) bærænde-ye Pehtemali-ye qæbli winner-EZ probable-EZ previous 'the previous probable winner'}

The unacceptability of (27) in context A where the adjective qæbbli 'previous' is interpreted as a temporal modifier and the fact that the epistemic adjective Pehtemali 'probable' cannot be used in context $\mathrm{C}$ where the two readings of qæabli 'previous' cooccur, as shown in (28), suggest that the position of epistemic adjectives is higher than $\mathrm{T}_{\mathrm{N}}$, but lower than ordinalP. This is illustrated in (29).

(28) \#bærænde-ye Pehtemali-ye qæbli-ye qæbli

winner-EZ probable-EZ previous-EZ previous

'\#the previous previous probable winner' 


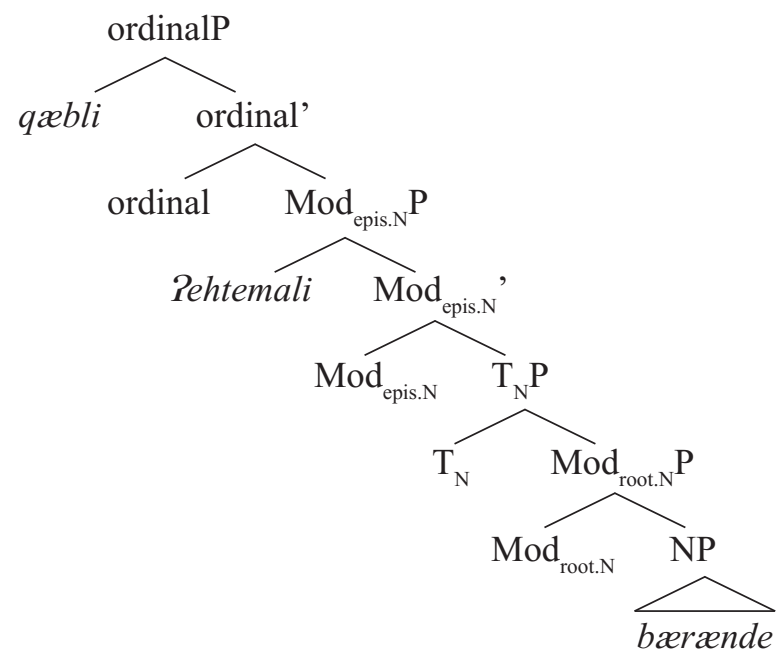

Base-generated higher than $T_{N}$, the epistemic adjective is evaluated with regard to the speaker's knowledge at the speech time.

Interestingly, as shown in (30), epistemic adjectives cannot be focalized crossing over ordinalP; the adjective qæbli 'previous' contains a presuppositional condition on the modified noun and is EXISTENCE-IMPLYING (see Musan 1997, 1999): what already exists cannot be probable.

\section{(30) \#bærænde-ye qæbli-ye Rehtemali winner-EZ previous-Ez probable intended: 'the previous probable winner'}

\subsection{Persian 'Possible': Epistemic/Root Adjective}

As discussed in Hacquard (2010), considering different structural positions for epistemic and root modal auxiliaries (e.g., can and must) in the verbal spine disambiguates the epistemic/root meaning of these elements. In a similar vein, considering different structural positions for epistemic and root modal adjectives in the nominal spine disambiguates the epistemic/root meaning of the Persian modal adjective momken 'possible'. This adjective can be interpreted as an epistemic or a root modal adjective, as shown in (31).

(31) pasox-ha-ye momken dær Pin Pemtehan answer-PL-Ez possible in this exam 'the possible answers in this exam'

a) epistemic reading: the answers that are possible, given what is known by the speaker at the speech time.

b) root reading: the answers that are possible, given the rules/circumstances of the examination event at the exam time. 
The analysis presented in this article accounts for the two readings of the adjective momken 'possible' in (31); when merged in Spec, $\operatorname{Mod}_{\text {epis. N }} \mathrm{P}$, it is interpreted as in (31a), and when merged in Spec,Mod ${ }_{\text {root. }} \mathrm{P}$, it is interpreted as in (31b). Thus, we can say that in the lexicon there is only one momken which is neutral with respect to the modal base, and that the epistemic and the root meanings of this adjective come from the two different syntactic positions it may occupy in the functional hierarchy of the noun phrase.

\section{CONCLUSION}

In this article, I showed that the modification of noun phrases with temporal expressions and the temporal relation between predicates and their arguments provide evidence for considering some extending-into-time perspective in the nominal domain. Then, on the basis of the location-in-specifier approach to adjectival syntax and the morphological expression of time within the nominal domain, I indicated that tense combines with nominals although $\mathrm{T}_{\mathrm{N}}$ does not share similar features with its clausal counterpart. After that, I discussed that the adjective qæbli 'previous' is structurally ambiguous: in the specifier of $\mathrm{T}_{\mathrm{N}} \mathrm{P}$, it is interpreted as a temporal modifier and in the specifier of ordinalP, it is interpreted as an ordinal modifier. This structural ambiguity put forth a justification for the fixed order of the epistemic and root modal adjectives with regard to the temporal adjective. Root adjectives are base-generated lower than $\mathrm{T}_{\mathrm{N}}$ in the specifier of $\operatorname{Mod}_{\text {root. }} \mathrm{P}$ and are evaluated with regard to the NP event; the time of the event is signaled by $T_{N}$, which refers to the existence/occurrence time of the modified noun, and the individual is the modified noun. Epistemic adjectives are basegenerated higher than $\mathrm{T}_{\mathrm{N}}$ in the specifier of $\operatorname{Mod}_{\text {epis. }} \mathrm{P}$ and are evaluated in the context of the speech event, that is, with regard to the speech time and the speaker's knowledge. This is what I proposed in (4), repeated here in (32).

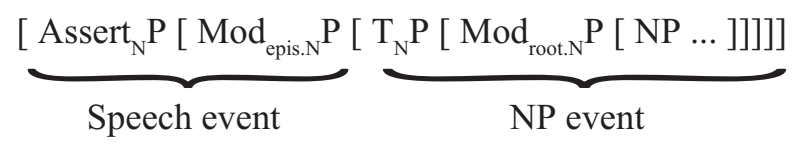

The last remark I wish to make here is that the nominal assertion Assert $_{\mathrm{N}}$ is a logical operator, co-indexed with its clausal counterpart, Assert (see Hacquard's 2010). The question that may arise is how a noun phrase can be asserted, or more precisely, how a speech act mood projection can be present in the nominal domain (if at all). I leave the semantic nature of Assert $_{\mathrm{N}}$ and its relation to D for further research.

\section{References}

ABOH, Enoch (2004) "Topic and Focus within D." Linguistics in the Netherlands 21, 1-12. ABOLGHASEMI, Mohsen (2002) tarix-e moxtæesær-e zæban-e farsi [The brief history of Persian]. Tehran: Tahoori. 
ABUSCH, Dorit (1988) "Sequence of tense, intensionality, and scope." Proceedings of the West Coast Conference on Formal Linguistics 7, 1-14.

ABUSCH, Dorit (1997) "Sequence of tense and temporal de re." Linguistics and Philosophy 20, 1-50.

ALEXIADOU, Artemis (2001) Functional structure in nominals: Nominalization and ergativity. Amsterdam: John Benjamins Publishing Company.

ALEXIADOU, Artemis (2005) Tense (and mood) in the nominal domain(?). Paper presented at The Workshop on the Linguistic Representation of Tense and Mood, Stuttgart.

ANGITSO, Michael T. (2015) "The limits of the DP/CP parallelism: Evidence from Tiv." Semantics-Syntax Interface 2/2, 141-156.

BURTON, Strang C. (1997) "Past tense on nouns as death, destruction, and loss." In: Proceedings of NELS 27. Amherst, MA: University of Massachusetts, 65-77.

BUTLER, Jonny (2003) “A minimalist treatment of modality.” Lingua 113, 967-996.

CINQUE, Guglielmo (1994) "Evidence for partial N-movement in the Romance DP." In: G. Cinque/J. Koster/J. Pollock/L. Rizzi/R. Zanuttini (eds), Paths towards universal grammar: Studies in honor of Richard S. Kayne. Washington, D.C.: Georgetown University Press, $85-110$.

CINQUE, Guglielmo (1999) Adverbs and functional heads: A crosslinguistic perspective. New York and Oxford: Oxford University Press.

CINQUE, Guglielmo (2004) "Issues in adverbial syntax." Lingua 114, 683-710.

CINQUE, Guglielmo (2010) The syntax of adjectives: A comparative study. Cambridge, MA: MIT Press.

CINQUE, Guglielmo (2013) "Cognition, universal grammar, and typological generalizations." Lingua 130, 50-65.

CINQUE, Guglielmo (2015) "A note on 'other'." In: E. Brandner/A. Czypionka/C. Freitag/ A. Trotzke (eds), Charting the Landscape of Linguistics: Webschrift for Josef Bayer. University of Konstanz, 22-27.

COMRIE, Bernard (1985) Tense. Cambridge: Cambridge University Press.

DELAZERO, Octav E./Parvane GERAEE (2014) "Ezafe constructions as relative clauses: Semantic arguments." Semantics-Syntax Interface 1/1, 75-81.

ENÇ, Mürvet (1987) “Anchoring conditions for tense.” Linguistic Inquiry 18, 633-657. VON FINTEL, Kai (2006). "Modality and language." In: D.M. Borchert (ed.), Encyclopedia of Philosophy (2nd ed.). Detroit: MacMillan Reference USA.

GHOMESHI, Jila (1997) "Non-projecting nouns and the Ezafe construction in Persian." Natural Language and Linguistic Theory 15, 729-788.

GIUSTI, Giuliana (2005) "At the left periphery of the Romanian noun phrase." In: M. Coene/L. Tasmowski (eds), On Space and Time in Language. Cluj: Clusium, 23-49.

HACQUARD, Valentine (2006) Aspects of modality. PhD dissertation, MIT, Cambridge, MA.

HACQUARD, Valentine (2010) "On the event relativity of modal auxiliaries." Natural Language Semantics 18/1, 79-114. 
HACQUARD, Valentine (2011) "Modality." In: C. Maienborn/K. von Heusinger/P. Portner (eds), Semantics: An international handbook of natural language meaning. Berlin: Mouton de Gruyter, 1484-1515.

ILKHANIPOUR, Negin (2015) sefat-e væjhi dær zæban-e farsi [Modal adjectives in Persian]. Tehran: Nashr-e-Markaz.

ILKHANIPOUR, Negin/Octav E. DELAZERO (2013) Selectional properties of Persian modal adjectives. Talk presented at ICIL5, Bamberg.

KRATZER, Angelika (1977) "What 'must' and 'can' must and can mean." Linguistics and Philosophy 1, 337-355.

KRATZER, Angelika (1981) “The notional category of modality.” In: H.-J. Eikmeyer/H. Rieser (eds), Words, worlds, and contexts: New approaches in word semantics. Berlin: Walter de Gruyter, 38-74.

KRATZER, Angelika (1991) "Modality." In: A. von Stechow and D. Wunderlich (eds), Semantics: An international handbook of contemporary research. Berlin: de Gruyter, 639-650.

KRATZER, Angelika (2012) Modals and conditionals: New and revised perspectives. Oxford: Oxford University Press.

KRATZER, Angelika (2013) Modality for the 21st century. Keynote talk at the 19th International Congress of Linguistics, Geneva.

LARSON, Richard/Hiroko YAMAKIDO (2005) Ezafe and the deep position of nominal modifiers. Barcelona Workshop on Adjectives and Adverbs.

LECARME, Jacqueline (1996) "Tense in the nominal system: The Somali DP.” In: J. Lecarme/J. Lowenstamm/U. Shlonsky (eds), Studies in Afroasiatic grammar. The Hague: Holland Academic Graphics, 159-178.

LECARME, Jacqueline (2004) "Tense in nominals." In: J. Guéron and J. Lecarme (eds), The syntax of time. Cambridge, MA: MIT Press, 440-475.

LECARME, Jacqueline (2008) "Tense and modality in nominals." In: J. Guéron/J. Lecarme (eds), Time and modality. Dordrecht: Springer, 195-225.

MUSAN, Renate (1995) "On the temporal interpretation of noun phrases." PhD dissertation, MIT.

MUSAN, Renate (1997) "Tense, predicates, and lifetime effects." Natural Language Semantics 5, 271-301.

MUSAN, Renate (1999) "Temporal interpretation and information-status of noun phrases." Linguistics and Philosophy 22, 621-661.

NARROG, Heiko (2005) “On defining modality again.” Language Sciences 27, 165-192.

NORDLINGER, Rachel/Louisa SADLER (2003) "The syntax and semantics of tensed nominals." In: Proceedings of LFG03 Conference. State University of New York at Albany.

NORDLINGER, Rachel/Louisa SADLER (2004a) "Nominal tense in cross-linguistic perspective." Language 80/4, 776-806.

NORDLINGER, Rachel/Louisa SADLER (2004b) "Tense beyond the verb: Encoding clausal tense/aspect/mood on nominal dependents." Natural Language and Linguistic Theory 22, 597-641. 
NUYTS, Jan (1993) "Epistemic modal adverbs and adjectives and the layered representation of conceptual and linguistic structure." Linguistics 31, 933-969.

NUYTS, Jan (2001) Epistemic modality, language, and conceptualization. Amsterdam \& Philadelphia: John Benjamins.

NUYTS, Jan (2006) "Modality: Overview and linguistic issues." In: W. Frawley (ed.), The expression of modality. Berlin: Mouton de Gruyter, 1-26.

OGIHARA, Toshiyuki (1995) "The semantics of tense in embedded clauses." Linguistic Inquiry 26, 663-679.

PALMER, Frank R. (1990) Modality and the English modals. New York: Routledge.

PALMER, Frank R. (2001) Mood and modality (2nd ed.). Cambridge: Cambridge University Press.

PANAGIOTIDIS, Phoevos (2011) "Categorial features and categorizers." The Linguistic Review 28/3, 365-386.

PANAGIOTIDIS, Phoevos (2015) Categorial features: A generative theory of word class categories. Cambridge: Cambridge University Press.

PORTNER, Paul (2009) Modality. Oxford: Oxford University Press.

SADLER, Louisa/Rachel NORDLINGER (2001) "Nominal tense with nominal scope: A preliminary sketch." In: Proceedings of LFG01 Conference. University of Hongkong, Hongkong.

SAMIIAN, Vida (1994) "The Ezafe construction: Some implications for the theory of X-bar syntax." In: Mehdi Marashi (ed.), Persian studies in North America. Betheda, MD: Iranbooks, 17-41.

SCOTT, Gary-John (2002) "Stacked adjectival modification and the structure of nominal phrases." In: G. Cinque (ed.), Functional structure in DP and IP: The cartography of syntactic structures, vol. 1. Oxford: Oxford University Press, 91-120.

STEEDMAN, Mark (1997) "Temporality." In: J. van Benthem/A. ter Meulen (eds), Handbook of logic and language. Amsterdam: Elsevier.

STOWELL, Tim (1982) "On tense of infinitives." Linguistic Inquiry 13, 561-570.

STOWELL, Tim (1992) "Aspects of tense theory." GLOW Newsletter 28, 48-49.

STOWELL, Tim (1995) "The phrase structure of tense.” In: J. Rooryck,/L. Zaring (eds), Phrase structure and the lexicon. Dordrecht: Kluwer, 277-291.

STOWELL, Tim (2000) Tense and modals. Presented at International Round Table 'The Syntax of Tense and Aspect', Université Paris III - Sorbonne Nouvelle, 5-18 November.

STOWELL, Tim (2007) "The syntactic expression of tense." Lingua 114, 437-463.

TONHAUSER, Judith (2006) The temporal semantics of noun phrases: Evidence from Guarani. PhD dissertation, Stanford University.

TONHAUSER, Judith (2007) "What is nominal tense? A case study of Paraguayan Guaraní." In: Proceedings of Semantics of Under-represented Languages (SULA) III. Amherst, MA: GLSA Publications. 


\section{Summary \\ TENSE AND MODALITY IN THE NOMINAL DOMAIN}

It is well discussed in the literature that epistemic modals $\left(\operatorname{Mod}_{\text {epis }}\right)$ are base-generated higher than Tense (T), while non-epistemic/root modals $\left(\mathrm{Mod}_{\text {root }}\right)$ are base-generated lower than T, and that high modals are evaluated in the context of the speech event (i.e., with regard to the speaker at the speech time), whereas low modals are evaluated in the context of the VP event (with regard to an argument at the event time).

In this study, looking with favour upon the presence of tense and modal functional projections in the nominal domain, and following the idea that adjectives are basegenerated in the specifiers of distinct functional projections, I argue that, similar to the structure of CPs, epistemic and root modal elements have different positions in DPs; epistemic adjectives appear in the specifier of $\mathrm{Mod}_{\text {epis. }} \mathrm{P}$ above nominal tense $\left(\mathrm{T}_{\mathrm{N}} \mathrm{P}\right)$, while root adjectives appear in the specifier of $\operatorname{Mod}_{\text {root. }} \mathrm{P}$ below $\mathrm{T}_{\mathrm{N}} \mathrm{P}$, where nominal tense is the time of the existence or occurrence of the modified noun.

With this aim in view, first, I show that the ambiguity of the adjective qæebli 'previous' is due to the two positions this adjective can occupy: the specifier of $\mathrm{T}_{\mathrm{N}} \mathrm{P}$ and the specifier of ordinalP, where the adjective receives temporal and ordinal interpretations, respectively.

Next, I explain that this structural ambiguity is observed when qæabli 'previous' cooccurs with root adjectives, such as qabel-e-PePtemad 'reliable'. This suggests that the position of root adjectives is lower than $T_{N}$, where it is interpreted with respect to the modified noun at the event time.

With epistemic adjectives, such as Pehtemali 'probable', the adjective qæabli 'previous' is not ambiguous; it can be interpreted only as an ordinal modifier. This implies that the epistemic modal is higher than $\mathrm{T}_{\mathrm{N}}$, where it is evaluated with regard to the speaker's knowledge at the speech time.

Thus, we see that the interaction of temporal and modal adjectives in DPs provides evidence for a structural hierarchy in the nominal domain parallel to its counterpart at the clausal level.

Keywords: adjectives, modality, nominals, Persian, tense

\section{Povzetek \\ ČAS IN MODALNOST V SAMOSTALNIŠKI DOMENI}

Znanstvene razprave pogosto umeščajo epistemske modalne prvine $\left(\operatorname{Mod}_{\text {epis }}\right) \mathrm{v}$ bazično tvorjen položaj nad Tense (T), medtem ko so neepistemske oziroma korenske modalne prvine $\left(\mathrm{Mod}_{\text {root }}\right)$ bazično tvorjene nižje od $\mathrm{T}$. Višje umeščene modalne prvine so ovrednotene v kontekstu govornega dogodka (v odnosu do govorca v času govora), medtem ko so nižje umeščene modalne prvine ovrednotene v kontekstu dogodka znotraj glagolske zveze VP (v odnosu do argumenta v času dogodka). 
V pričujoči študiji, ki sledi pristopom, ki dopuščajo časovne in modalne funkcionalne projekcije $\mathrm{v}$ samostalniški domeni in privzemajo, da so pridevniki bazično tvorjeni v določilih ločenih funkcionalnih projekcij, trdimo, da imajo - podobno, kot je to znano za zgradbo vezniške zveze $\mathrm{CP}$ - epistemske in korenske modalne prvine $\mathrm{v}$ določilniških zvezah (DP) različne položaje: epistemski pridevniki se pojavljajo v določilu $\operatorname{Mod}_{\text {epis. }} \mathrm{P}$ nad samostalniškim časom $\left(\mathrm{T}_{\mathrm{N}} \mathrm{P}\right)$, medtem ko se korenski pridevniki pojavljajo v določilu $\operatorname{Mod}_{\text {root. }} \mathrm{P}$ pod zvezo $\mathrm{T}_{\mathrm{N}} \mathrm{P}$, kjer samostalniški čas predstavlja čas obstoja ali čas pojavitve modificiranega samostalnika.

Tako najprej pokažemo, da dvoumnost pridevnika qæbli 'prejšnji' izhaja iz dveh skladenjskih položajev, ki jih lahko ta pridevnik zavzame: določilo zveze $\mathrm{T}_{\mathrm{N}} \mathrm{P}$ in določilo zveze ordinalP, kjer pridevnik prejme časovno in vrstilniško interpretacijo.

Nato razložimo, da do zgradbene dvoumnosti pride, ko se pridevnik qæbli 'prejšnji' pojavi s korenskimi pridevniki, kakršen je qabel-e- Pe Ptemad 'zanesljiv'. Tako pokažemo, da je položaj korenskih pridevnikov nižje od $\mathrm{T}_{\mathrm{N}}$, kjer je interpretiran $\mathrm{v}$ odnosu do modificiranega samostalnika $\mathrm{v}$ času dogodka.

Z epistemskimi pridevniki, kakršen je Pehtemali 'verjeten', pridevnik qæbli 'prejšnji’ ni dvoumen; lahko je interpretiran le kot vrstilniški modifikator. To pokaže, da je epistemska prvina višje od $\mathrm{T}_{\mathrm{N}}$, kjer je ovrednotena $\mathrm{v}$ odnosu do govorčevega vedenja $\mathrm{v}$ času govora.

V prispevku tako pokažemo, da interakcija časovnih modalnih pridevnikov v zvezi DP dokazuje skladenjsko hierarhijo v samostalniški domeni, ki je vzporedna tisti na ravni stavka.

Ključne besede: pridevniki, modalnost, nominalne prvine, perzijščina, čas 